Journal of Educational Method and Technology Vol. 1 No. 2, September 2018

P-ISSN 2622-8459 E-ISSN 2622-8467

http://ejournal.unima.ac.id/index.php/jemtec

\title{
Demonstration Method In Introduce Secondary Color Learning
}

\author{
N E D Surwayaningrat ${ }^{1}$, J M Sumilat $^{2}$ \\ ${ }^{1,2}$ Universitas Negeri Manado, Indonesia \\ corresponding aunthor: ${ }^{1}$ nidewiekha@unima.ac.id
}

\begin{abstract}
Early childhood education is very important for the child's future.[1] early childhood is the age of gold where the development of children into a period of development is very decisive. The mix of primary colors (Red, yellow, blue), will become secondary color, and this is generally not understood by kindergarten children. To introduce the secondary color requires a method of learning that shows directly how to obtain it, such as the method of demonstration learning. The purpose of this study is to improve the ability to recognize the secondary color in children with the method of demonstration learning. This research uses Class Action Research method. The subjects of this study were students of group B kindergarten GMIM Hosiana Tumatangtang amounted to 14 children. The results obtained through two cycles with the application of demonstration methods can improve the ability to introduce secondary color.
\end{abstract}

\section{Keywords : Introduce Secondary Color, Demonstration Method.}

\section{Introduction}

Early childhood education is very important for the child's future [1], early childhood is the age of gold where the development of children into a period of development is very decisive[2], because at this time that determines the beginning of the character formation, personality, and cognitive child [3]. Child Kindergarten aged 4-6 years is included in Early Childhood Education and is a pre-school child who must get stimulus in the field of education to grow up in entering the level of further education. Learning in kindergarten is learning that introduce $s$ the child with the things he / she encounters in everyday life. For example color recognition and naming [4].

The mix of primary colors (Red, yellow, blue), will become secondary color, and this is generally not understood by kindergarten children. To introduce the secondary color requires a method of learning that shows directly how to 
obtain it [5][6], such as the method of demonstration learning. Implementation of demonstration methods can improve the smooth motor development in kindergarten children while building children's knowledge [7].

The purpose of this study is to improve the ability to introduce the secondary color in children with the method of demonstration learning. With the method of teaching demonstration teachers can show directly on the children how the process of coloring primary and produce a new color of secondary color, so that learning feels more meaningful for the child [8] while providing knowledge about the color naming in children.

\section{Methods}

This study uses classroom action research, and more clearly described in the following chart [9]. The stages of this research consist of 4 stages, namely 1) Planning: the researcher preparing the plan by making the learning process plan [10], 2) Implementation of Research, in implementing the researcher assisted by the student of PGPAUD State University of Manado, 3) Observation, research and the next stage 4) reflection, at this stage the researcher analyzes the research and obstacles encountered in the study, then analyzes the results of learning that produce and retrieve the results of research. For data information techniques, knowledge and interviews. The subjects of this study were students of group B of kindergarten GMIM Hosiana Tumatangtang 14 children, consisting of 6 girls and 8 boys. Data analysis techniques used by using the star symbol (*) as a sign of achievement at the Directorate General of National Education Dikas[11].

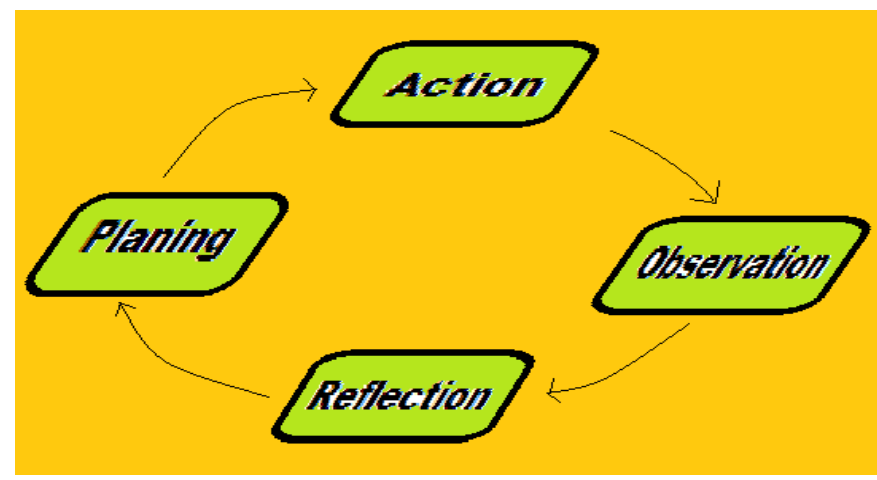

Figure 1. Classroom Action Research Cycle

\section{Results and Discussion}

The implementation of classroom action is carried out in two cycles. In cycle 1 there are 3 or $21.43 \%$ of children get one star sign from 14 children who follow the learning activities. This shows that the ability of the three children can still be categorized not yet have the ability to introduce the secondary colors of green, purple, and orange. While 5 or $35.71 \%$ of children get a two star sign, here they can already know the color yellow, while the color purple and orange has not recognized the children. Then 4 or $28.57 \%$ of children get a three star sign, which 
is categorized the child already knows all the secondary colors but require the help of color samples. Furthermore 2 or $14.28 \%$ of children get four stars, which indicates that they already have the ability to introduce the secondary color of green, unggu, and orange well even without help. So in cycle I there are 6 or $42.86 \%$ of children who succeed, from the number of children who have good development in terms of recognizing the green, purple, and orange color of the target $80 \%$.

The achievement of cycle 1 has not met the success criteria. This happens because the level of concentration and listening from each child is different[12]. Therefore, to introduce the colors in the Kindergarten children of group B is not enough with only one time but it takes several times the experiment or demonstration and addition of the teachers who provide the settled knowledge [13]. It is also in the process of secondary color recognition, image images that are not yet available to provide a clear appeal to children. Therefore, the attention and responsibility as well as the achievements of cycle 1, so you do not have to worry about things like super strong images that again like Avengers, and Hulk as well as Sofia and Frozen princess.

The result of the 2nd cycle of 14 children following the learning, no children get one star sign. This indicates that the child is familiar with the secondary color, while 1 or $7.14 \%$ of children get a two star sign indicating that the child's ability is still categorized as developing. This child can already know the color green, and orange, but for the color purple has not been recognized by the child. Then 7 children or $50 \%$ of students get three star marks that are categorized children already know all the secondary colors but still need the help of color samples. Furthermore, 6 or $42.86 \%$ of children get four stars indicating that they already have the ability to introduce secondary colors, namely green, purple, and orange, which means they already know the color well without help. So, in this 2nd cycle there are 13 or $92.86 \%$ of children who have known the secondary color well. The result of this research on the second cycle has reached the target of research criteria that $80 \%$ of children experience good development in terms of secondary color, therefore this research is said to be successful.

The use of demonstration methods on secondary color recognition learning has been able to provide experience in children so that it becomes a knowledge of secondary color names[14]. The results obtained through two cycles with the implementation of demonstration methods can improve the ability to introduce secondary color.

The use of demonstration methods on secondary color recognition learning has been able to provide experience in children thus building an understanding of the process of secondary color formation and becoming a knowledge of secondary color names [13] Knowledge built through understanding will provide more stimulation to the child's memory of secondary color naming than the knowledge gained through rote[15].

\section{Conclusion}

The results obtained through two cycles with the application of demonstration methods can improve the ability to introduce secondary color. 
Journal of Educational Method and Technology Vol. 1 No. 2, September 2018

P-ISSN 2622-8459 E-ISSN 2622-8467

http://ejournal.unima.ac.id/index.php/jemtec

\section{References}

[1] Ginsburg KR. The importance of play in promoting healthy child development and maintaining strong parent-child bonds. Pediatrics. 2007 Jan 1;119(1):182-91.

[2] Mutiah D. Psikologi bermain anak usia dini. Jakarta. Prenada Media Group. 2015. h.vi

[3] Permono H. Peran orangtua dalam optimalisasi tumbuh kembang anak untuk membangun karakter anak usia dini. Seminar Nasional Psikologi UMS. Parenting. 2013.

[4] Bornstein MH. On the development of color naming in young children: Data and theory. Brain and language. 1985 Sep 1;26(1):72-93.

[5] Bracken BA, Crawford E. Basic concepts in early childhood educational standards: A 50-state review. Early Childhood Education Journal. 2010 Mar 1;37(5):421-30.

[6] Smith A, Duncan J, Marshall K. Children's perspectives on their learning: Exploring methods. Early Child Development and Care. 2005 Aug 1;175(6):473-87.

[7] Purnamasari NK, Negara IG, Ke SP, Suara IM. Penerapan Metode Demonstrasi Melalui Kegiatan Melipat Kertas (Origami) Untuk Meningkatkan Perkembangan Motorik Halus Anak Tk Kemala Bhayangkari 1 Denpasar. Jurnal Pendidikan Anak Usia Dini Undiksha. 2014 Jul 1;2(1)

[8] Roza MM. Pelaksanaan Pembelajaran Sains Anak Taman Kanak-Kanak Aisyiyah Bustanul Athfal 29 Padang. Jurnal Pesona Paud. 2012 Oct 12;1(05).

[9] Pearson J. Participation and control in EAP writing assessment. InPoster presented at EALTA SIG Seminar on the assessment of writing and assessment for academic purposes, university of Warwick 2015 Feb 5.

[10] Kemmis S, McTaggart R, Nixon R. The action research planner: Doing critical participatory action research. Springer Science \& Business Media; 2013 Nov 12.

[11] Depdiknas, Pedoman Penilaian. Jakarta. Kemendiknas dirjen mandas dan menengah direktorat Pembinaan TK SD. 2010.

[12] Faber Taylor A, Kuo FE. Children with attention deficits concentrate better after walk in the park. Journal of attention disorders. 2009 Mar;12(5):402-9

[13] Gillies RM, Ashman AF. The effects of cooperative learning on students with learning difficulties in the lower elementary school. The Journal of Special Education. 2000 Apr;34(1):19-27.

[14] French L. Science as the center of a coherent, integrated early childhood curriculum. Early Childhood Research Quarterly. 2004 Jan 1;19(1):138-49.

[15] Driscoll MP. Psychology of learning. Boston, Allyn and Bacon. 2000 